\title{
Mapping myasthenia gravis-associated $T$ cell epitopes on human acetylcholine receptors in HLA transgenic mice
}

\author{
Huan Yang, ${ }^{1}$ Elzbieta Goluszko, ${ }^{1}$ Chella David, ${ }^{2}$ David K. Okita, ${ }^{3}$ Bianca Conti-Fine, ${ }^{3}$ \\ Teh-sheng Chan, ${ }^{1}$ Mathilde A. Poussin, ${ }^{1}$ and Premkumar Christadoss ${ }^{1}$ \\ ${ }^{1}$ Department of Microbiology and Immunology, University of Texas Medical Branch, Galveston, Texas, USA \\ ${ }^{2}$ Department of Immunology, Mayo Clinic, Rochester, Minnesota, USA \\ ${ }^{3}$ Department of Biochemistry, Molecular Biology, and Biophysics, University of Minnesota, St. Paul, Minnesota, USA
}

Address correspondence to: Premkumar Christadoss, Department of Microbiology and Immunology, University of Texas Medical Branch, Galveston, Texas 77555-1070, USA. Phone: (409) 772-5857; Fax: (409) 747-6869; E-mail: pchrista@utmb.edu.

Received for publication September 20, 2001, and accepted in revised form March 19, 2002.

\begin{abstract}
Susceptibility to myasthenia gravis (MG) is positively linked to expression of HLA-DQ8 and DR3 molecules and negatively linked to expression of the DQ6 molecule. To elucidate the molecular basis of this association, we have induced experimental autoimmune MG (EAMG) in mice transgenic for HLA-DQ8, DQ6, and DR3, and in DQ8 $\times$ DQ6 and DQ8 $\times D R 3 \mathrm{~F}_{1}$ transgenic mice, by immunization with human acetylcholine receptor (H-AChR) in CFA. Mice expressing transgenes for one or both of the HLA class II molecules positively associated with MG (DQ8 and DR3) developed EAMG. T cells from DQ8 transgenic mice responded well to three cytoplasmic peptide sequences of $\mathrm{H}-\mathrm{AChR}(\alpha 320-337, \alpha 304-322$, and $\alpha 419-437)$, of which the response to $\alpha 320-337$ was the most intense. DR3 transgenic mice also responded to this sequence very strongly. $\mathrm{H}-\mathrm{ACh}$ - and $\alpha 320-337$ peptide-specific lymphocyte responses were restricted by HLA class II molecules. Disease resistance in DQ6 transgenic mice was associated with reduced synthesis of anti-AChR IgG, IgG 2 , and $\operatorname{IgG}_{2 \mathrm{c}} \mathrm{Ab}$ 's and reduced IL-2 and IFN- $\gamma$ secretion by H-AChR- and peptide $\alpha 320-337$-specific lymphocytes. Finally, we show that DQ8 imparts susceptibility to EAMG and responsiveness to an epitope within the sequence $\alpha 320-337$ as a dominant trait.
\end{abstract}

J. Clin. Invest. 109:1111-1120 (2002). DOI:10.1172/JCI200214255.

\section{Introduction}

The human autoimmune disease myasthenia gravis (MG) is characterized by $\mathrm{T}$ cell and $\mathrm{Ab}$ responses to muscle nicotinic acetylcholine receptor (AChR). Highaffinity, anti-AChR Ab's, upon binding at the neuromuscular junction, activate complement and accelerate AChR destruction, while causing failure of neuromuscular transmission and the resulting myasthenic symptoms (1-3). However, AChR-specific CD4 ${ }^{+} \mathrm{T}$ cells, which can be detected in most MG patients (3), likely have an important role in MG, because they modulate the synthesis of anti-AChR Ab and may be the prime movers in the pathogenesis of MG. Experimental autoimmune MG (EAMG) is a model of MG, and it is induced in experimental animals by immunization with purified AChR from different sources. Immunization of C57BL/6 mice with Torpedo californica AChR (T-AChR) in CFA causes activation of specific $\mathrm{T}$ and $\mathrm{B}$ cells, and synthesis of anti-AChR Ab (4). As in MG, the anti-AChR $A b$ 's bind at the mouse neuromuscular junction, activate the complement cascade, and cause increased AChR loss and EAMG $(1,3,5,6)$. MHC class II gene products influence the $\mathrm{T}$ cell and $\mathrm{Ab}$ response to the AChR, and susceptibility to EAMG $(7,8)$. In the B6.C$\mathrm{H}-2^{\mathrm{bm} 12}(\mathrm{bm} 12)$ strain, a gene conversion event between $\mathrm{I}-\mathrm{E} \beta^{\mathrm{b}}$ and I-A $\beta^{\mathrm{b}}$ altered three amino acids in the C-terminal half of the first domain of $A \beta^{\mathrm{b}}\left(\mathrm{Ile}_{67} \rightarrow\right.$ Phe; $\operatorname{Arg}_{70} \rightarrow \mathrm{Gln}$; $\mathrm{Thr}_{71} \rightarrow$ Lys) and resulted in relative resist- ance to EAMG development (9). In C57BL/6 mice, depletion of $\mathrm{CD}^{+}$cells in vivo prevented EAMG and also induced clinical remission, demonstrating the critical role of $\mathrm{CD}^{+}$cells in EAMG pathogenesis (10).

HLA-DQ $\beta$ chain polymorphism and increased frequency of HLA-DQ8 and HLA-DR3 alleles have been associated with human MG susceptibility $(11,12)$. On the other hand, the DQ6 allele has been suggested to be negatively associated with MG (13). To study the role of human HLA class II molecules in MG, Raju et al. examined the susceptibility to EAMG in B10 mice transgenic for human HLA-DQ8 and DQ6 class II molecules (14). The HLA transgenic mice do not have the endogenous I-A $\beta$ and I-E $\alpha$ molecules and therefore only express human HLA-DQ8, DQ6, or DR3 transgenic class II molecules $(14,15)$. HLA transgenic mice developed EAMG following immunization with T-AChR $(14,15)$. Further, transgenic expression of HLA-DQ6 correlated with reduced susceptibility to EAMG (14).

In the EAMG-susceptible C57BL/6 (I-A $\left.{ }^{\mathrm{b}}\right)$ mice immunized with T-AChR, the sequence region 146-169 of the T-AChR $\alpha$ subunit forms an immunodominant epitope for $\mathrm{CD}^{+} \mathrm{T}$ cell sensitization (16-19). Several studies have suggested that sensitization of $\mathrm{CD} 4^{+}$cells to epitopes within that immunodominant sequence region was important for EAMG development. The AChRimmune lymphocytes of $\mathrm{bm} 12$ mice exhibited a reduced proliferative response to epitopes within the $\alpha 146-169$ 
sequence (16-19). Neonatal tolerance to T- $\alpha 146-162$ peptide, and nasal or systemic administration to adult C57BL/6 mice of synthetic peptides within the sequence T- $\alpha 146-169$, prevented EAMG development after T-AChR immunization (19-22). When using systemic high doses of a T- $\alpha 146-162$ peptide, the resulting tolerance was mediated by the Fas/Fas ligand pathway, apoptosis, and clonal anergy of AChR-reactive $\mathrm{CD}^{+}$cells (23). Unlike T cells from wild-type C57BL/6 mice, those from HLA-DQ8 and HLA-DR3 transgenic mice immunized with T-AChR recognized, primarily, two promiscuous determinants within residues 141-160 and $170-190$ of the human AChR (H-AChR) $\alpha$ subunit (15). In this study, we induced EAMG by H-AChR immunization and characterized the H-AChR T cell epitopes involved in activation of $\mathrm{T}$ cells, and the cytokines secreted by the anti-H-AChR T cells. Toward that goal, we immunized HLA transgenic mice with $\mathrm{H}$-AChR derived from the human muscle-like TE671 cell line. H-AChR-immunized HLA-DQ8, DR3, DQ8 $\times$ DR3 $F_{1}$, and DQ8 $\times$ DQ6 $F_{1}$ mice developed clinical EAMG, whereas HLA-DQ6 mice were less susceptible. The cytoplasmic H-AChR peptide $\alpha 320-337$ (H- $\alpha 320-337)$ was the dominant $\mathrm{T}$ cell epitope for DQ8, DR3, and DQ8 $\times$ DQ6 $F_{1}$ mice. The HLA class II-restricted lymphocyte response against $\mathrm{H}-\mathrm{AChR}$ and peptide $\mathrm{H}-\alpha 320-337$ and susceptibility to EAMG were inherited as a dominant trait in DQ8 $\times$ DQ6 $\mathrm{F}_{1}$ mice.

\section{Methods}

Mice. We used transgenic mice deficient in the mouse MHC class II molecules, which bear only a human HLA$\mathrm{DQ}\left(\mathrm{A} \beta^{0}\right.$.DQ8 or $\mathrm{A} \beta^{0}$.DQ6) or $\mathrm{DR}\left(\mathrm{A} \beta^{0}\right.$.DR3) molecule. The mice express functional HLA-DQ8 (HLADQA1*0301/DQB1*0302), DQ6 (HLA-DQA1*0103/ DQB1*0601), or DR3 (HLA-DRA1*0101/DRB1*0301) genes in the C57BL/10 background. All of the transgenic mice, except DQ8 $\times$ DQ6 $F_{1}$ mice, were obtained after the tenth backcross generation to $\mathrm{C} 5 \mathrm{BL} / 10$ mice. The A $\beta^{0}$.DR3 (DR3) mice were mated with $A \beta^{0}$.DQ8 (DQ8) mice to obtain the DQ8 $\times$ DR3 $F_{1}$ mice. The fourth backcross generation of $A \beta^{0}$.DQ8 and $A \beta^{0}$.DQ6 (DQ6) mice were mated to derive DQ8 $\times \mathrm{DQ}^{6} \mathrm{~F}_{1}$ mice. In all of the transgenic mice, expression of HLA class II and absence of endogenous MHC class II molecules were verified by FACS and PCR $(14,15,24,25)$. The percentage of $\mathrm{CD}^{+}$and $\mathrm{CD}^{+}$cells in the peripheral blood leukocytes of transgenic mice before immunization was analyzed by flow cytometry as previously demonstrated (25). CD4 $4^{+}$cells in the different strains were: DQ6, $15.68 \% \pm 3.55 \%$; DQ8, $14.02 \% \pm 2.20 \%$; DR3, $15.73 \% \pm 3.03 \%$; and DQ8 $\times$ DR3 $F_{1}, 16.08 \% \pm 4.41 \%$; while $\mathrm{CD}^{+}$cells were as follows: $\mathrm{DQ} 6,10.14 \% \pm 1.12 \%$; DQ8, $11.42 \% \pm 2.76 \%$; DR3, $11.34 \% \pm 4.89 \%$; and DQ8 $\times$ DR3 $F_{1}, 10.6 \% \pm 1.60 \%$. No significant differences between these strains of mice were found. Therefore, the immune system in HLA transgenic mice developed normally, with appropriate expression and functionality of MHC class II molecules. All transgenic lines were initially bred at the Mayo Clinic and then bred and housed in the viral Ab-free barrier facility at the University of Texas Medical Branch. All experiments were performed according to the Animal Care and Use Committee guidelines.

Purification of human AChR, biological activity, and SDSPAGE. H-AChR was purified from the TE671 cell line (American Type Culture Collection, Rockville, Maryland, USA), which expresses $H$-AChR, by an $\alpha$-neurotoxin affinity column. The TE671 cell line was cultured in $150-\mathrm{cm}^{2}$ cell culture flasks at $37^{\circ} \mathrm{C}$ in Dulbecco's modification of Eagle's medium supplemented with 2 $\mathrm{mM} / 1 \mathrm{~L}$-glutamine, and $10 \%$ of FBS in the presence of $100 \mathrm{U} / \mathrm{ml}$ penicillin $\mathrm{G}$ and $100 \mu \mathrm{g} / \mathrm{ml}$ streptomycin. Confluent cells were harvested every 3-4 days. Cells were washed in homogenization buffer containing 5 $\mathrm{mM} / 1$ Tris ( $\mathrm{pH} 7.8$ ), $10 \mathrm{mM} / 1$ EDTA, $10 \mathrm{mM} / 1$ EGTA, $0.1 \mathrm{~g} / \mathrm{l}$ phenylmethylsulfonyl fluoride, and $0.2 \mathrm{~g} / 1$ sodium azide. The cells were removed from the flask, and cells collected from 70-100 flasks were used for one affinity purification procedure. After washing, the pellet was resuspended in a small amount of homogenizing buffer, and 0.1 vol of $10 \%$ Triton (1\% Triton X-100) was added to the TE671 cells and agitated for 4 hours on a shaker at low speed at $4^{\circ} \mathrm{C}$. The extract was centrifuged for 30 minutes at $100,000 \mathrm{~g}$ at $4^{\circ} \mathrm{C}$. AChR containing supernatant was added to neurotoxin 3-agarose (Sigma Chemical Co., St. Louis, Missouri, USA) in a glass flask and agitated gently in a shaker for 4 hours at $4^{\circ} \mathrm{C}$. The next day, AChR extract/neurotoxin 3-agarose mixture was poured into a $1.5 \times 20-\mathrm{cm}$ Econo column (Bio-Rad Laboratories, Life Science Group, Hercules, California, USA). The mixture was poured down the sides of the column and the buffer allowed to run out of the column. After beads were packed, supernatants were allowed to run out of the column until a small amount covered the top. $\mathrm{NaCl} /$ Triton buffer was added to the top, and the column was washed with $100 \mathrm{ml}$ of buffer. Following this step, both the toxin affinity and hydroxylapatite columns were washed with $300 \mathrm{ml} 0.2 \%$ cholate buffer. Buffer from the top of both columns was removed, and $1 \mathrm{M}$ carbamylcholine buffer (26) (Sigma Chemical Co.) was added. Then the hydroxylapatite column, but not the neurotoxin 3 column, was washed with $100 \mathrm{ml}$ of 1 $M$ carbamylcholine buffer. Plastic tubing from both the columns was connected to a pump. The peristaltic pump was run at a rate of $50 \mathrm{ml} / \mathrm{h}$, and the mixture was allowed to circulate for 14-16 hours. The connection between the toxin affinity and the hydroxylapatite columns was removed, and H-AChR was eluted with $152 \mathrm{mM}$ phosphate elution buffer (26) into a fraction collector. The total yield from each purification varied with an average of $5 \mathrm{mg}$ pure $\mathrm{H}-\mathrm{AChR}$ protein from 40 to $60 \mathrm{~g}$ TE671 cells. We evaluated the ability of the H-AChR preparations to bind specifically to $\left[{ }^{125} \mathrm{I}\right] \alpha-$ bungarotoxin $\left(\left[{ }^{125} \mathrm{I}\right] \alpha-\mathrm{BTX}\right)$. One microgram of affinity-purified H-AChR had 92-219 nM of $\alpha$-BTX-binding sites. SDS-PAGE confirmed the purity of fetal H-AChR 


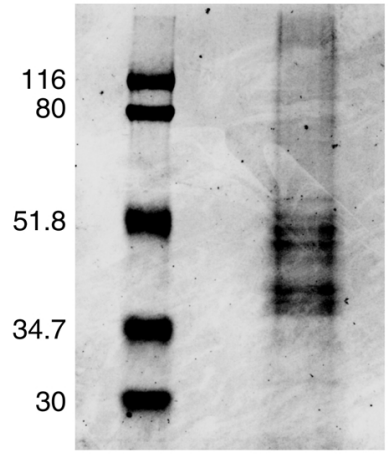

Figure 1

SDS-PAGE separation of affinity-purified H-AChR protein. Standard protein markers and $20 \mu \mathrm{l}$ of sample buffer containing $10 \mu \mathrm{g}$ $\mathrm{H}$-AChR protein were loaded on a $7 \times 8-\mathrm{cm}$ gel. PAGE was run in Mini-Protean II Electrophoresis Cell (Bio-Rad Laboratories) at 50 milli-Ampere for 2 hours and stained with Coomassie blue.

preparations with appropriate molecular weight of $\alpha$ (in duplicate), $\beta, \gamma$, and $\delta$ subunits (Figure 1) (27).

Peptides. The peptides used in this study were synthesized by parallel synthesis (28). Most of them were 14-20 residues long and overlapped by three to five residues. They spanned most of the H-AChR $\alpha$ subunit sequence. Their position in the AChR $\alpha$ subunit and their sequences are reported in Table 1 . The synthesis and characterization of these peptides have been reported (29-33). They were successfully used to identify the epitope repertoire of $\mathrm{CD}^{+}$cells from MG patients (29-33).

Induction of EAMG and clinical evaluation of the disease. DQ8, DR3, DQ6 (eight mice each), and ten $\mathrm{DQ} 8 \times \mathrm{DR} 3 \mathrm{~F}_{1}$ mice were immunized with $\mathrm{H}$-AChR $(20$ $\mu \mathrm{g}$ per mouse) in CFA on days 0,30 , and 60 . The mice were evaluated for clinical EAMG, and their muscle weakness was graded as follows. Grade 0: normal strength without any muscle weakness; grade 1: definite weakness of the forelimbs with a characteristic hunched, chin-down posture and flaccid tail, after exercise involving 20-30 consecutive paw grips on the top steel grids of the animal cage; grade 2: grade 1 weakness at rest; grade 3: severe weakness with paralysis involving all the limbs (quadriplegia) accompanied by dehydration and moribundity. Serum from individual mice was collected before first immunization and on days 15,45 , 75 , and 90 after first immunization.

Lymphocyte proliferative response in vitro to the $H-A C b R$ and mapping of $H-A C b R$ epitopes recognized by $T$ cells in $D Q 8, D Q 6$, $D R 3$, and DQ8 $\times D Q 6 F_{1}$ mice. DQ8, DQ6, $\mathrm{DR} 3$, and $\mathrm{DQ} 8 \times \mathrm{DQ} 6 \mathrm{~F}_{1}$ transgenic mice were immunized in the footpads with $20 \mu \mathrm{g}$ H-AChR in CFA. After 7 days, pooled draining (popliteal and inguinal)

\section{Table 1}

lymph node cells (LNCs) at $4 \times 10^{5}$ cells in $200 \mu \mathrm{l}$ were exposed in triplicate to each of the H-AChR- $\alpha(\mathrm{H}-\alpha)$ subunit peptides $(40 \mu \mathrm{g} / \mathrm{ml})$ and $\mathrm{H}-\mathrm{AChR}(0.5 \mu \mathrm{g} / \mathrm{ml})$. Inguinal, paraortic, and axillary LNCs of individual mice derived on day 90 of the long-term experiment were cultured in triplicate with $\mathrm{H}-\alpha 320-337$ peptide (40 $\mu \mathrm{g} / \mathrm{ml})$ or H-AChR $(0.5 \mu \mathrm{g} / \mathrm{ml})$. The culture medium contained RPMI-1640, supplemented with $10 \%$ FCS, penicillin $\mathrm{G}(100 \mathrm{U} / \mathrm{ml})$ streptomycin $(100 \mu \mathrm{g} / \mathrm{ml})$, L-glutamine $(2 \mathrm{mM}), 2$-mercaptoethanol $\left(3 \times 10^{-5} \mathrm{M}\right)$, and HEPES buffer $(25 \mathrm{mM})$. The cells were cultured for 5 days at $37^{\circ} \mathrm{C}$ in humidified $5 \% \mathrm{CO}_{2}$-enriched air, and pulse-labeled with $\left[{ }^{3} \mathrm{H}\right] \mathrm{TdR}(1 \mu \mathrm{Ci}$ per well $)$ for $18-20$ hours before harvesting. The ${ }^{3} \mathrm{H}$ incorporation was determined in a Beckman beta scintillation counter (Beckman Coulter Inc., Fullerton, California, USA). The results are expressed as $\Delta \mathrm{cpm}$ (cpm with antigen minus cpm with media).

Anti-DQ and $-D R$ Ab inhibition studies. DR3 and DQ8 mice (four of each) were immunized with H-AChR (20 $\mu \mathrm{g}$ per mice) in CFA. A week later, the mice were euthanized, and the pooled draining popliteal and inguinal LNCs in triplicate wells were cultured for 5 days with $\mathrm{H}$-AChR $(0.5 \mu \mathrm{g} / \mathrm{ml})$, with or without mAb's specific for HLA-DQ (Leinco Technologies Inc., St. Louis, Missouri, USA; clone 1a3) or HLA-DR molecules (PharMingen, San Diego, California, USA; clone G46-6, dialyzed to remove sodium azide). The extent of cell proliferation was determined from the incorporation of ${ }^{3} \mathrm{H}$-thymidine.

Serum anti-AChR $A b$ assay. To detect cross-reactive auto-Ab to mouse muscle AChR (M-AChR), crude mouse muscle extract containing M-AChR was incubated in Triton buffer with [ $\left.{ }^{125} \mathrm{I}\right] \alpha$-BTX $\left(5 \times 10^{-9} \mathrm{M}\right.$; Amersham Life Sciences Inc., Arlington Heights, Illinois, USA) for 1 hour. One microliter of serum of each mouse was added. Normal mouse serum (bled from

Human AChR $\alpha$ chain overlapping synthetic peptides ${ }^{A}$
1-14 SEHETRLVAKLFKD

19-34 VRPVEDHRQWEVTVG

48-67 QIVTTNVRLKQQWVDYNLKW

76-93 KKIHIPSEKIWRPDLVLY

101-120 AVIKFTKVLLQYTGHITWTP

135-154 IVTHFPFDEQNCSMKLGTWTYDGS

166-185 DLSNFMESGEWVIKESRGWK

181-200 SRGWKHSVTYSCCPDTPYLD

203-218 YHFVMQRLPLYFIVNV

230-249 GLVFYLPTDSGEKMTLSISV

280-297 FTMVFVIASIIITVIVIN

304-322 STHVMPNWVRKVFIDTIPN

329-347 MKRPSREKQDKKIFTEDID

352-368 SGKPGPMGFHSPLIK

387-400 KSDQESNNAAAEWK

419-437 IGGTLAVFAGRLIELNQQG
12-27 FKDYSSWRPVEDHRQ

32-51 TVGLQLIQLINVDEVNQIVT 63-80 YNLKWNPDDYGGVKKIHI 89-105 DLVLYNNADGDFAIVKF 118-130 WTPPAIFKSYCEI 151-168 YDGSWAINPESDQPDLS 181-195 SRGWKHSVTYSCCPD 191-207 SCCPDTPYLDITYHFVM 214-233 FIVNVIIPCLLFSFLTGLVF 261-280 VELIPSTSSAVPLIGKYMLF 293-308 VIVINTHHRSPSTHVM 320-337 IPNIMFFSTMKRPSREKQ 343-356 TEDIDISDISGKPG 376-393 IEGIKYIAETMKSDQESN 403-421 AMVMDHILLGVFMLVCIIG
${ }^{A}$ The single-letter notations of the amino acids are: $A$, alanine; $C$, cysteine; $D$, aspartic acid; $E$, glutamic acid; $F$, phenylalanine; $G$, glycine; $H$, histidine; I, isoleucine; $K$, lysine; L, leucine; $M$, methionine; $\mathrm{N}$, asparagine; $\mathrm{P}$, proline; $\mathrm{Q}$, glutamine; $\mathrm{R}$, arginine; $\mathrm{S}$, serine; $\mathrm{T}$, threonine; $\mathrm{V}$, valine; $\mathrm{W}$, tryptophan; $\mathrm{Y}$, tyrosine. 

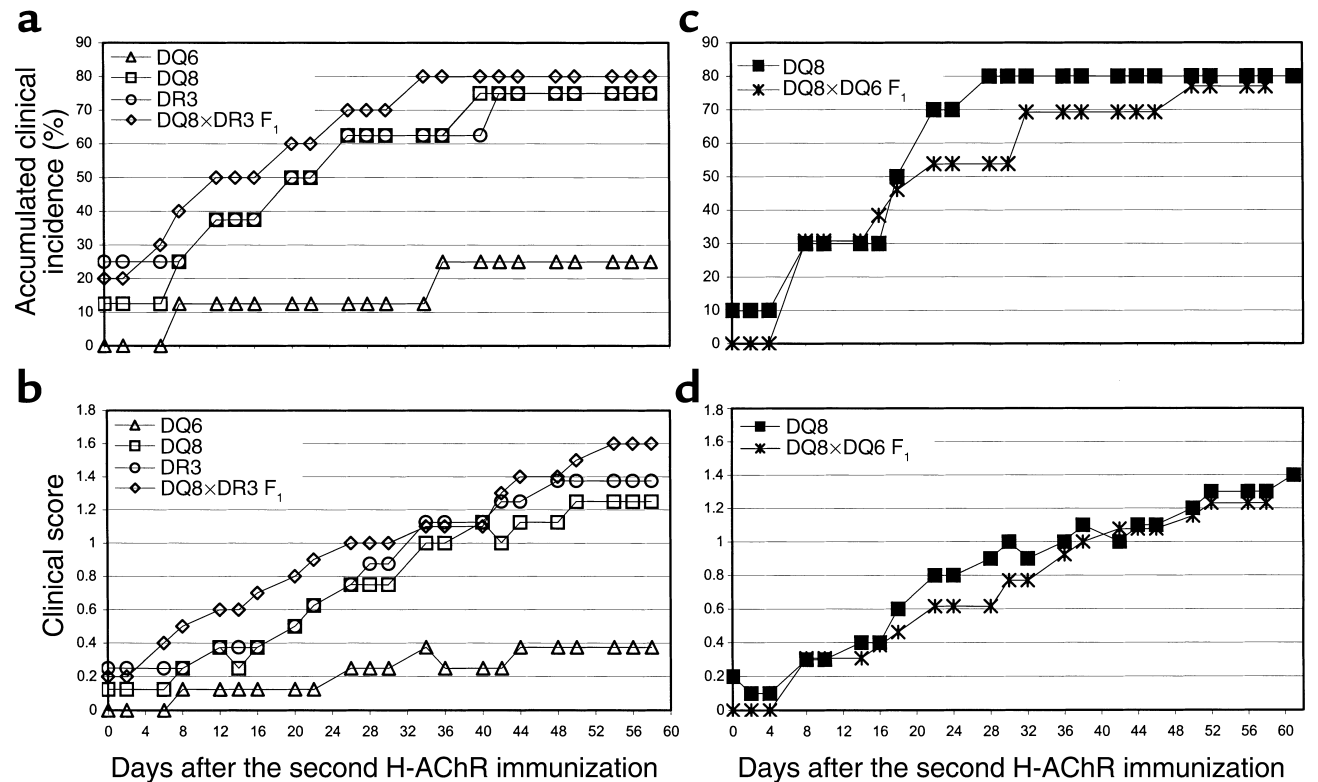

\section{Figure 2}

(a and $\mathbf{b})$ Kinetics of the accumulated clinical EAMG incidence $(\mathbf{a})$ and mean clinical score $(\mathbf{b})$ in DQ6, DQ8, DR3, and DQ8 $\times$ DR3 $F_{1}$ transgenic mice. DQ6 mice's mean clinical scores (severity) were significantly lower than those of DQ8 and DR3 (from day 42 to the end of the experiment) and DQ8 $\times D R 3 F_{1}$ mice (from day 20 to the end of the experiment) after a second $\mathrm{H}$-AChR immunization. $P<0.05$, Student's $t$ test. In Fisher's exact probability test, the difference in the clinical incidence between DQ8 and DQ6, and DR3 and DQ6 was significant at $P=0.060$. (c and d) Clinical EAMG incidence $(\mathbf{c})$ and mean clinical score $(\mathbf{d})$ of DQ8 and DQ8 $\times$ DQ6 $F_{1}$ transgenic mice.

mice before first immunization) served as control. After overnight incubation at $4^{\circ} \mathrm{C}$, goat anti-mouse IgG (Jackson ImmunoResearch Laboratories Inc., West Grove, Pennsylvania, USA) was added to $1 \mathrm{ml}$ of $\left[{ }^{125} \mathrm{I}\right] \alpha$ BTX-labeled AChR. After 4 hours, the tubes were centrifuged, and the pellets were washed with $1 \mathrm{ml}$ of Triton buffer, centrifuged again, and counted in a gamma counter. The AChR precipitated, minus the control value, gave the serum $\mathrm{Ab}$ amounts in nanomoles $(\mathrm{nM})$ of $\alpha$-BTX-binding sites bound per liter of serum.

ELISA of anti-M-AChR Ig isotype. Affinity-purified M-AChR $(0.5 \mu \mathrm{g} / \mathrm{ml})$ was coated onto a 96-well microtiter plate in $0.1 \mathrm{M}$ carbonate bicarbonate buffer ( $\mathrm{pH}$ 9.6) overnight at $4^{\circ} \mathrm{C}$. The plates were blocked with $2 \% \mathrm{BSA}$ in PBS at room temperature for $30 \mathrm{~min}$ utes. Diluted serum samples of $100 \mu \mathrm{l}\left(\mathrm{IgG}, \mathrm{IgG}_{1}\right.$, $\operatorname{IgG}_{2 \mathrm{~b}}$, and $\operatorname{IgG}_{2 \mathrm{c}} 1: 2500$; $\left.\operatorname{IgM} 1: 100\right)$ were added and incubated at $37^{\circ} \mathrm{C}$ for 90 minutes. After four washes, horseradish peroxidase-conjugated anti-mouse IgM, $\operatorname{IgG}, \operatorname{IgG}_{1}$, and $\operatorname{IgG}_{2 \mathrm{~b}}$ (Caltag Laboratories, Burlingame, California, USA) and anti-mouse $\operatorname{IgG}_{2 c}$ (PharMingen), diluted 1:1000 in PBS 0.05\% Tween-20, were added and incubated at $37^{\circ} \mathrm{C}$ for 90 minutes. Subsequently, 0.3 $\mathrm{mg} / \mathrm{ml}$ of diammonium 2,2'-azino-bis-(3-ethylbenzothiazoline-6-sulfonate) substrate (ABTS) solution was added to the $\operatorname{IgM}, \operatorname{IgG}, \operatorname{IgG}_{1}$, and $\operatorname{Ig} \mathrm{G}_{2 \mathrm{~b}}$ plates and $100 \mu \mathrm{l}$ of avidin-labeled peroxidase (Sigma Chemical Co.) at $2.5 \mu \mathrm{g} / \mathrm{ml}$ was added to the $\operatorname{IgG}_{2 c}$ plate and incubated for 30 minutes. Subsequently, the peroxidase indicator substrate ABTS, in $0.1 \mathrm{M}$ citric buffer, $\mathrm{pH} 4.35$, was added in the presence of $\mathrm{H}_{2} \mathrm{O}_{2}$, and the mixture was allowed to develop color at room temper- ature in the dark. Plates were read at a wavelength of $405 \mathrm{~nm}$. Serially diluted anti-AChR sera were used as a positive control, and normal mouse serum (collected from mice before $\mathrm{H}-\mathrm{AChR}$ immunization) was used for background determination. The results are expressed as $\triangle \mathrm{OD}$ (OD from sera after AChR immunization minus OD from sera before AChR immunization).

Radioimmunoassay of $M-A C h R$ content. 0.1 - $\mathrm{ml}$ aliquots of [125I] $\alpha$-BTX-labeled $\left(5 \times 10^{-9} \mathrm{M}\right)$, Triton X-100-solubilized mouse muscle extract, both with and without benzoquinonium $\left(10^{-3} \mathrm{M}\right)$, were mixed with $10 \mu \mathrm{l}$ of antiAChR serum. The resulting complex was precipitated by goat anti-mouse serum and then sedimented by centrifugation, washed in $1 \mathrm{ml}$ of Triton buffer, and sedimented again. Radioactivity of the pellet was counted in a Packard gamma counter (Packard Instrument Co., Meriden, Connecticut, USA), and cpm with benzoquinonium was subtracted from cpm of experimental samples without benzoquinonium. The concentration of AChR was expressed as $\mathrm{PM}$ of $\left[{ }^{125} \mathrm{I}\right] \alpha$-BTX-binding sites per gram of mouse carcass.

ELISA of cytokines secreted by cultured LNCs. At the end of the long-term experiment, draining LNCs (inguinal, paraaortic, and axillary) from individual mice were cultured in 48-well, flat-bottomed plates in the presence of $\mathrm{H}-\mathrm{AChR}(0.5 \mu \mathrm{g} / \mathrm{ml})$ or $\mathrm{H}-\alpha 320-337$ peptide $(40 \mu \mathrm{g} / \mathrm{ml})$; and at 48,72 , or 96 hours, the supernatant was collected for IL-2, IL-10, and IFN- $\gamma$ measurement. Wells in ELISA plates (Immunol 2; Dynatech Laboratories, Chantilly, Virginia, USA) were coated with $2 \mu \mathrm{g} / \mathrm{ml}(50 \mu \mathrm{l}$ per well) of one of the anti-cytokine (IL-2, IFN- $\gamma$, and IL-10; PharMingen) mAb's in $0.1 \mathrm{M}$ carbonate buffer, $\mathrm{pH} 8.2$ 


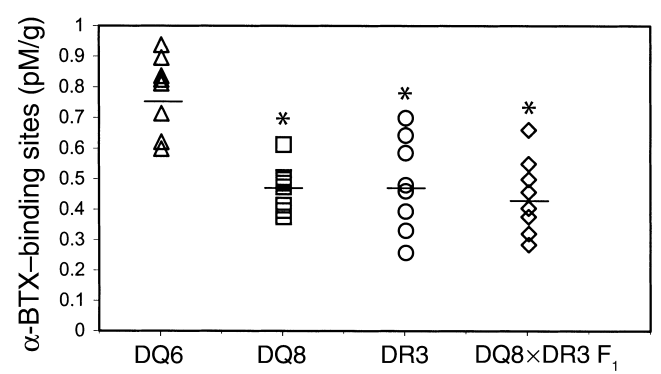

Figure 3

Muscle AChR content in AChR-immunized transgenic mice. Individual mouse carcasses were extracted to measure muscle AChR ( $\alpha$-BTX-binding sites) by radioimmunoassay and expressed as $\mathrm{PM}$ $\alpha$-BTX-binding sites per gram of mouse carcass. DQ6 mice had increased amounts of functional muscle AChR compared with DQ8, DR3, and DQ8 $\times$ DR3 $\mathrm{F}_{1}$ mice. ${ }^{*} P<0.01$, Student's $t$ test. There was no difference in the muscle AChR content between normal DQ8 (1.16 $\pm 0.10 \mathrm{pM} / \mathrm{g})$, DQ6 $(0.94 \pm 0.07 \mathrm{pM} / \mathrm{g})$, and DR3 $(1.25 \pm 0.08 \mathrm{pM} / \mathrm{g})$ mice.

overnight at $4^{\circ} \mathrm{C}$. The plates were blocked with $200 \mu \mathrm{l}$ of $10 \%$ FCS in PBS for 2 hours. Supernatant sample (100 $\mu \mathrm{l})$ and various dilutions of cytokine standards (PharMingen) were added, titered to the linear portion of the absorbance/concentration curve in duplicate, and incubated overnight at $4^{\circ} \mathrm{C}$. After the plates were washed six times with PBS and Tween-20 (0.05\%), $100 \mu \mathrm{l}$ biotinylated anti-cytokine $\mathrm{mAb}$ (with different epitopic determinants than the Ab used to coat ELISA plates) at 1 $\mu \mathrm{g} / \mathrm{ml}$ in PBS containing 10\% FCS were added for 45 minutes at room temperature. After vigorous washing, $100 \mu \mathrm{l}$ of avidin-labeled peroxidase (Sigma Chemical Co.) at $2.5 \mu \mathrm{g} / \mathrm{ml}$ was added and incubated for $30 \mathrm{~min}$ utes. Subsequently, the peroxidase indicator substrate ABTS in $0.1 \mathrm{M}$ citric buffer, $\mathrm{pH} 4.35$, was added in the presence of $\mathrm{H}_{2} \mathrm{O}_{2}$, and the $\mathrm{OD}$ was measured at $405 \mathrm{~nm}$ using the ELISA reader from Molecular Devices Corp. (Sunnyvale, California, USA). The negative (background) controls were culture medium. The concentration of specific cytokine samples was measured based on cytokine standards (IFN- $\gamma$ and IL-10, PharMingen; IL-2, R\&D Systems Inc., Minneapolis, Minnesota, USA).

\section{Results}

$H$-AChR immunization induced clinical EAMG in DQ8, $D R 3, D Q 8 \times D R 3 F_{1}$, and $D Q 8 \times D Q 6 F_{1}$ mice. DQ6 mice were relatively resistant to clinical EAMG when immunized with T-AChR (14). In our study, before the second AChR immunization, two of eight DR3 mice (25\%) and one of eight DQ8 mice (12.5\%) developed grade 1 EAMG. After the second immunization, five of eight DQ8 (62.5\%) and four of eight DR3 mice (50\%) developed grade 1 or 2 EAMG. The accumulated total clinical incidence at the end of the experiment was six of eight (75\%) for DQ8 and DR3 mice. The time course of the accumulated incidence of clinical EAMG and the time of onset of the clinical disease are illustrated in Figure $2 \mathrm{a}$ and the time course of the clinical score (mean grade) is illustrated in Figure 2b. Only two of eight DQ6 mice (25\%) developed low-grade, clinical EAMG after the third immunization. Therefore, DQ6 mice are relatively resistant to EAMG and develop less severe disease when immunized with either $\mathrm{H}$-AChR (this study) or T-AChR (14).

Since both DQ8 and DR3 alleles are positively associated with $M G$, we examined the susceptibility to EAMG of DQ8 $\times$ DR3 $F_{1}$ mice, which express both the DQ8 and the DQ3 molecules. Eight of ten DQ8 $\times$ DR3 $\mathrm{F}_{1}$ mice $(80 \%)$ developed clinical EAMG, and one died at 44 days after the second immunization because of severe disease (Figure 2, a and b). Expression of I-E $\alpha^{\mathrm{K}} \beta^{\mathrm{b}}$ (I-E) molecule (equivalent to human DR molecule) in B10 mice suppressed EAMG development (34). However, in HLA transgenic mice, expression of the DR3 molecule in the presence of EAMG susceptible DQ8 molecule did not suppress clinical EAMG.

Next we examined whether simultaneous inheritance of the EAMG-susceptible DQ8 allele and the EAMGresistant DQ6 allele leads to dominant susceptibility to EAMG. DQ8 $\times$ DQ6 $F_{1}$ mice developed clinical EAMG with an incidence and severity similar to those of DQ8 mice (Figure 2, c and d), suggesting the dominance of the DQ8 gene in determining EAMG susceptibility. Consistent with the clinical findings, the AChR content of mouse muscle, determined as $\alpha$-BTX-binding sites, was significantly lower in $\mathrm{H}$-AChR-immunized $\mathrm{DQ} 8, \mathrm{DR} 3$, and $\mathrm{DQ} 8 \times \mathrm{DR} 3 \mathrm{~F}_{1}$ mice than in the resistant DQ6 mice (Figure 3).

Reduced serum anti-AChR Ablevel in DQ6 mice, compared with $D Q 8, D R 3$, and $D Q 8 \times D R 3 F_{1}$ mice. Serum collected on days 15,45 , and 75 , after the beginning of the $\mathrm{H}$-AChR immunization, were evaluated for anti-MAChR Ab concentration by an $\alpha$-BTX radioimmunoassay. The anti-AChR $A b$ response of all the transgenic strains was low on day 15 after priming with $\mathrm{H}-\mathrm{AChR}$, and no differences were observed between transgenic

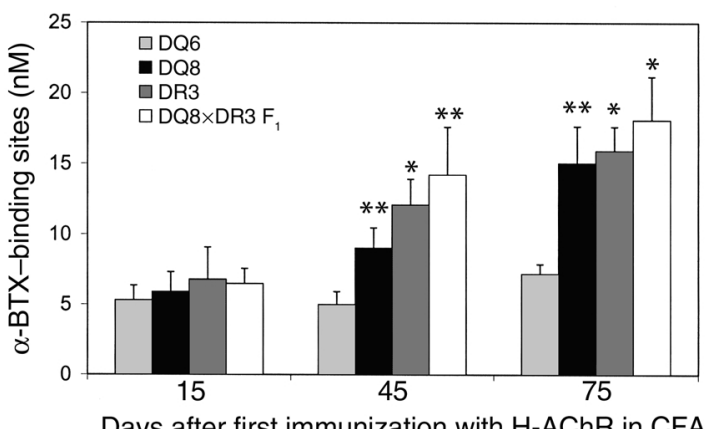

\section{Figure 4}

Reduced anti-AChR IgG response in DQ6 mice compared with DQ8, $D R 3$, and DQ8 $\times D R 3 F_{1}$ mice. Serum individually derived from DQ6, DQ8, DR3, and DQ8 $\times D R 3 F_{1}$ mice (eight mice of each group) on days 15,45 , and 75 after the first H-AChR immunization was measured for anti-mouse muscle AChR IgG level by $\alpha$-BTX radioimmunoassay. The mean value of cpm of prebleeding serum from all transgenic mice was similar (DQ8, $396 \pm 55$; DR3, $414 \pm 47$; DQ6, $\left.390 \pm 30 ; \mathrm{DQ} 8 \times \mathrm{DR} 3 \mathrm{~F}_{1}, 400 \pm 47\right)$. The error bars are SE. ${ }^{*} P<0.01$ and ${ }^{*} P<0.05$, Student's $t$ test. 

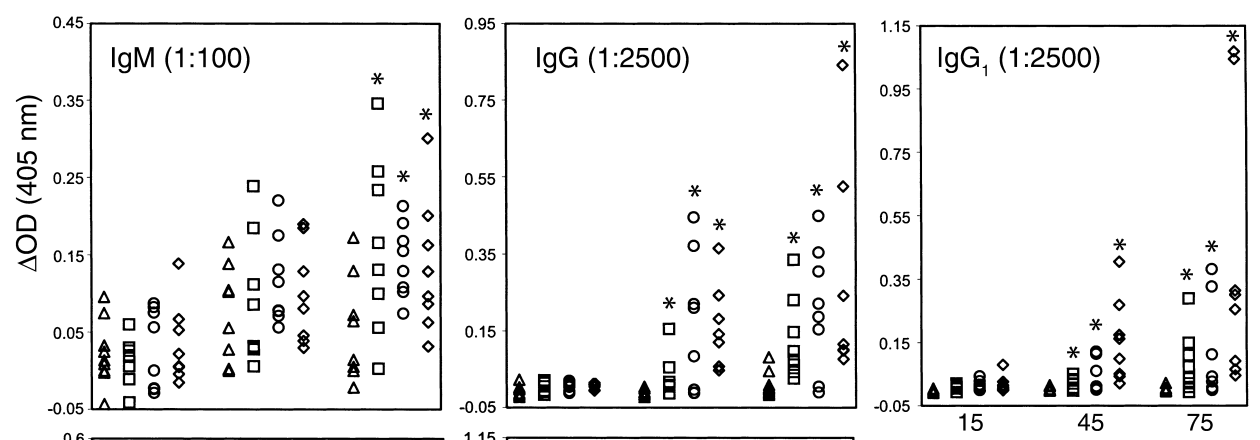

Figure 5

Suppressed secondary antiAChR $\lg G, \lg G_{1}, \lg G_{2 b}$, and $\operatorname{lgG}_{2 c} A b$ in DQ6 mice. Antimouse AChR isotype in serum was measured by ELISA on affinity-purified, mouse AChR-coated plates. $\triangle O D(405 \mathrm{nM})$, the value from immunized mouse sample, was subtracted from the preimmunized value. ${ }^{*} P>0.05$, Student's t test.
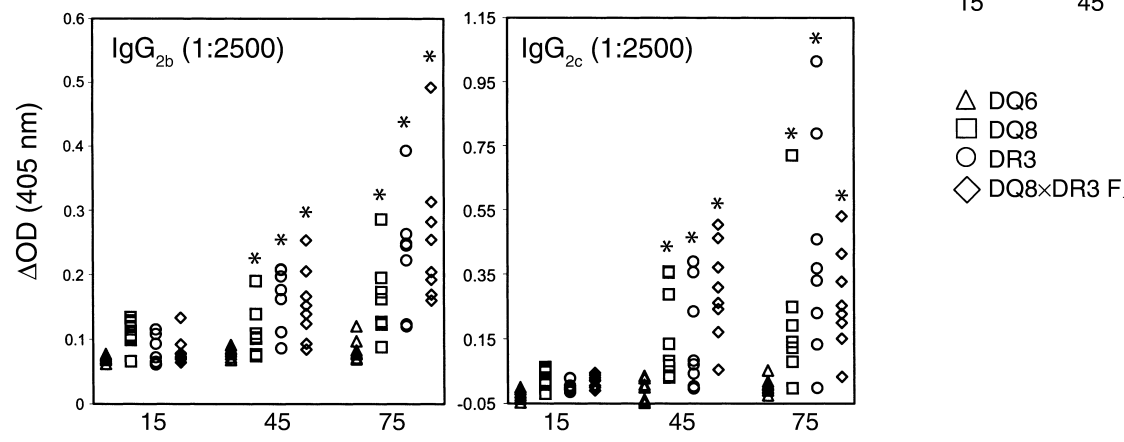

Days after first $\mathrm{H}$-AChR immunization

mice (Figure 4). However, at 45 days (15 days after the first $\mathrm{H}-\mathrm{AChR}$ boost) and at 75 days (15 days after second boost), DQ8, DR3, and DQ8 $\times$ DR3 $F_{1}$ mice had significantly higher concentrations of serum anti-MAChR Ab than did DQ6 mice (Figure 4). Therefore, the resistance of DQ6 mice to development of clinical EAMG could be due to the reduced production of cross-reactive $\mathrm{Ab}$ to mouse muscle AChR.

Reduced serum concentrations of anti-AChR IgG, IgG $I g G_{2 b}$, and $I g G_{2 c}$ in DQ6 mice compared with DQ8, DR3, and $D Q 8 \times D R 3 F_{1}$ mice. Next we examined whether the concentration in the serum of anti-AChR IgG isotypes correlated with development of EAMG in the EAMG-susceptible DQ8, DR3, and DQ8 $\times$ DR3 $\mathrm{F}_{1}$ mice, and in the relatively resistant DQ6 mice. Fifteen days after priming with $\mathrm{H}$-AChR, we did not observe significant differences in the primary anti-AChR $\operatorname{IgM} \mathrm{Ab}$ between DQ6 mice, and DQ8, DR3, and DQ8 $\times$ DR3 $F_{1}$ mice (Figure 5). However, the concentration of serum antiAChR IgM Ab level was very low in all of the transgenic mice at that time. On day 75 (after two booster doses of H-AChR), DQ8, DR3, and DQ8 $\times$ DR3 $F_{1}$ mice had significantly higher serum anti-AChR IgM responses than did DQ6 mice (Figure 5). As observed for the $\alpha$-BTX radioimmunoassay of anti-AChR Ab, also in the ELISA, the serum anti-AChR IgG Ab response was reduced in the DQ6 mice as compared with the DQ8, DR3, and DQ8 $\times$ DR3 $F_{1}$ mice (Figure 5). On days 45 and 75 (after one and two boosts with $\mathrm{H}$-AChR, respectively), DQ6 mice had significantly reduced serum concentrations of anti-AChR IgG $1, \operatorname{IgG}_{2 b}$, and $\operatorname{IgG}_{2 c}$ isotypes. Therefore, the relative resistance of EAMG in DQ6 mice was associated with reduced secondary response involving anti-AChR $\operatorname{IgG}_{1}, \operatorname{IgG}_{2 \mathrm{~b}}$, and $\operatorname{IgG}_{2 \mathrm{c}}$ Ab isotypes.
The sequence $\alpha 320-337$ of the $H$-AChR forms a dominant $T$ cell epitope for DQ8, DR3, and DQ8XDQ6 $F_{1}$ mice. We next mapped the T cell epitopes on the H-AChR $\alpha$ subunit by challenging LNCs from H-AChR-immunized DQ8, DR3, DQ6, and DQ8 $\times$ DQ6 $\mathrm{F}_{1}$ mice, with overlapping synthetic peptides spanning most of the sequence of the H-AChR $\alpha$ subunit. Peptide $\alpha 320$ 337 was most strongly recognized by $\mathrm{T}$ cells of H-AChR-immunized DQ8, DR3, and DQ8×DQ6 $F_{1}$ mice (Figure 6). Peptide $\alpha 304-322$ was a subdominant epitope in DQ8 mice. $\mathrm{H}-\mathrm{AChR}$-immunized $\mathrm{T}$ cells of DR3 mice responded well (>40,000 cpm) to numerous peptides of the H-AChR $\alpha$ subunit $(\alpha 320$ 337, $\alpha 376-393, \alpha 304-322, \alpha 261-280, \alpha 89-105$, and a76-93). H-AChR-immune DQ6 mouse T cells responded moderately $(20,000 \mathrm{cpm})$ to peptide $\alpha 304-322$ and did not respond to any other $\mathrm{H}-\mathrm{AChR}$ $\alpha$ subunit peptides. $\mathrm{H}-\mathrm{ACh}$-immune $\mathrm{T}$ cells from DQ8 $\times$ DQ6 $F_{1}$ mice responded to almost all of the peptides recognized by $\mathrm{H}$-AChR-immune $\mathrm{T}$ cells from DQ8 mice.

Reduced AChR-specific lymphocyte proliferation and production of IFN- $\gamma$ and IL-2 in DQ6 mice as compared with $D Q 8, D R 3$, and DQ8 $\times D Q 6 F_{1}$ mice. Ninety days after the first H-AChR immunization, LNCs from all the transgenic mice were cultured in vitro with $\mathrm{H}$-AChR or peptide $\mathrm{H}-\alpha 320-337$, and examined for lymphocyte proliferation and cytokine secretion. H-AChR- and H- $\alpha 320-337-$ specific proliferation was significantly lower for LNCs from DQ6 mice than for those from DQ8, DR3, and DQ8 $\times$ DQ6 $\mathrm{F}_{1}$ mice (Figure $7 \mathrm{a}$ ). We measured IL-2, IL-10, and IFN- $\gamma$ in supernatants collected after 48, 72, and 96 hours of culture, respectively. H-AChR- and H- $\alpha 320-337$-specific IFN- $\gamma$ and IL-2 
production was significantly higher in cultures of LNCs from DR3, DQ8, and DQ8 $\times D^{2} 6 F_{1}$ mice than in those of LNCs from DQ6 mice (Figure 7, b and c). There were no significant differences in IL-10 responses between different transgenic mice (Figure $7 \mathrm{~d}$ ).

$H-A C h R-$ and H- $\alpha 320-337$ peptide-specific lymphocyte responses in DQ8 and DR3 mice are HLA class II-restricted. DQ8 and DR3 mice were immunized with $\mathrm{H}-\mathrm{AChR}(20$ $\mu \mathrm{g}$ per mouse) in CFA. Seven days later, their pooled draining LNCs were stimulated in vitro with $\mathrm{H}$-AChR or $\mathrm{H}-\alpha 320-337$, in the presence or absence of anti-HLA-DQ or anti-HLA-DR Ab. Anti-HLA-DQ Ab inhibited the $\mathrm{H}-\mathrm{AChR}$ - and $\mathrm{H}-\alpha 320-337$-induced proliferative response of LNCs from DQ8, but not DR3, mice, while anti-HLA-DR Ab inhibited the H-AChRand $\mathrm{H}-\alpha 320-337$-induced proliferative response of LNCs from DR3, but not DQ8, mice (Figure 8).

\section{Discussion}

Although numerous studies have examined the association of HLA class II gene polymorphism with susceptibility to MG or other autoimmune diseases, the molecular mechanisms by which HLA class II genes influence the development of autoimmune diseases are still obscure. This is because the HLA system is very complex, and the presence of gene clusters and of linkage disequilibrium further complicates this issue. HLA transgenic mice were generated in an attempt to reduce this complexity in a biologically relevant setting. The HLA transgenic mice we used do not express endogenous class II molecules: thus, the only MHC class II gene products involved in antigen presentation in these mice are the human DQ8, DR3, or DQ6 molecules. These HLA class II transgenic mice expressed normal levels of $\mathrm{CD}^{+}$and $\mathrm{CD}^{+}$cells (25), confirming that the transgenic HLA class II molecules can interact with the mouse CD4 molecule and $\mathrm{T}$ cell receptors.

Previous studies used panels of overlapping synthetic peptides spanning the sequence of the different $\mathrm{H}$-AChR subunits, to examine the $\mathrm{CD}^{+} \mathrm{T}$ cell response of PBMCs from MG patients, or H-AChR-specific $\mathrm{CD}^{+} \mathrm{T}$ cell lines derived from $\mathrm{MG}$ patients, to identify H-AChR T cell epitopes (29-33, 35-43). Those studies identified a number of sequence regions recognized by $\mathrm{CD}^{+}$cells of $\mathrm{MG}$ patients, including a few immunodominant epitopes, which were recognized by the majority of MG patients on each human AChR subunit; several of those epitopes were within the H-AChR $\alpha$ subunit. Harcourt et al. reported that peptide 257-269 from H-AChR stimulated cells from six patients and no controls (42). However, MHC class II restriction of this peptide-induced lymphocyte response was not studied. Other studies $(44,45)$ demonstrated that the AChR sequence regions immunodominant for sensitization of $\mathrm{CD}^{+}$cells in $\mathrm{MG}$ patients could associate with a variety of purified DR
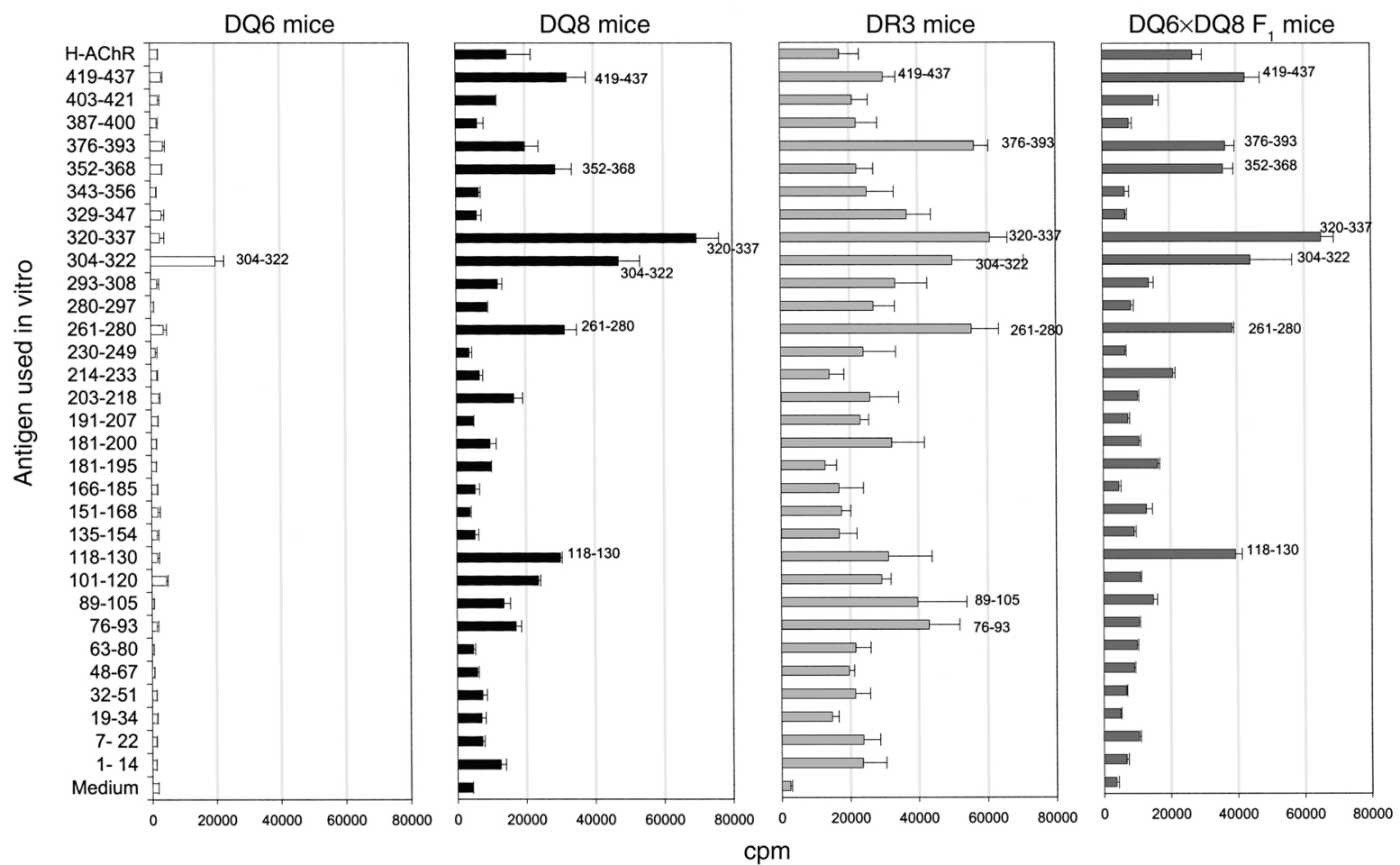

Figure 6

T cell epitope mapping on the $\mathrm{H}-\mathrm{AChR} \alpha$ subunit in DQ6, DQ8, DR3, and DQ8XDQ6 $\mathrm{F}_{1}$ transgenic mice immunized with $\mathrm{H}-\mathrm{AChR}$. The transgenic mice were immunized in the footpad with $\mathrm{H}-\mathrm{AChR}(20 \mu \mathrm{g})$ in CFA. Seven days later, draining LNCs (popliteal and inguinal) were exposed to each of the overlapping synthetic $\mathrm{H}$-AChR $\alpha$ subunit peptides $(40 \mu \mathrm{g} / \mathrm{ml})$ and $\mathrm{H}$-AChR $(0.5 \mu \mathrm{g} / \mathrm{ml})$, and ${ }^{3} \mathrm{H}$ incorporation was determined. The error bars are SE. 


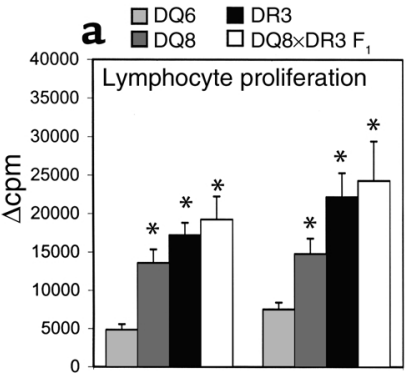

\section{b}
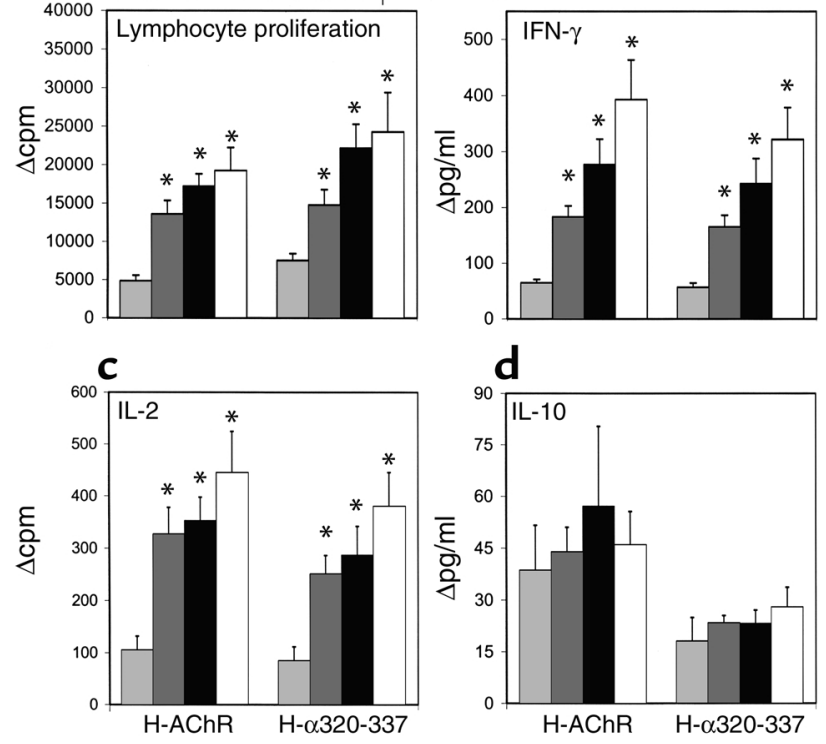

\section{Figure 7}

Reduced $\mathrm{H}$-AChR- and $\alpha 320-337$ peptide-specific lymphocyte proliferative response and IFN- $\gamma$ and IL-2 secretion in DQ6 mice compared with DQ8, DR3, and DQ8 $\times$ DR3 $F_{1}$ mice. At termination of the long-term experiment (day 90), LNCs from DQ6, DQ8, DR3, and DQ8 $\times D R 3 ~ F_{1}$ mice were cultured in vitro with $\mathrm{H}-\mathrm{AChR}(0.5 \mu \mathrm{g} / \mathrm{ml})$, peptide $\alpha 320-337(40 \mu \mathrm{g} / \mathrm{ml})$, and PBS, and supernatants collected after 48,72 , and 96 hours were used for IL-2, IL-10, and IFN- $\gamma$ measurement, respectively. Because of the reduced number of cells, the LNCs from two mice in one group were pooled. For the lymphocyte proliferation, total samples were six DQ6 mice and eight each of DQ8, DR3, and DQ8 $\times D R 3 F_{1}$ mice; for the supernatant cytokine test, total samples were three DQ6, seven DQ8, five DR3, and five DQ8 XDR3 $\mathrm{F}_{1}$ mice. (a) Lymphocyte proliferation is measured in $\Delta \mathrm{cpm}$ (cpm with antigen minus $\mathrm{cpm}$ with medium). Mean $\mathrm{cpm}$ with medium was: DQ6, 6363; DQ8, 6218; DR3, 6795; DQ8×DR3 F1, 7567. $\Delta c p m$ for T-AChR was: DQ6, 2152; DQ8, 7213; DR3, 9703; DQ8×DR3 $F_{1}$, 1046.4. (b and $\mathbf{c}$ ) Suppressed production of AChR-specific IFN- $\gamma(\mathbf{b})$ and IL-2 (c) in DQ6 mice compared with DQ8, DR3, and DQ8 XDR3 $\mathrm{F}_{1}$ mice. ${ }^{*} P<0.05$, Student's $t$ test. The error bars are SE. Mean values $(\mathrm{pg} / \mathrm{ml})$ with medium for IFN- $\gamma$ were: DQ6, 21.67; DQ8, 22.19; DR3 , 36.07; DQ8 $\times D R 3 ~ F_{1}, 26.59$; and for IL-2 were: DQ6, 27; DQ8, 54.18; DR3, 47.42; DQ8 $\times D R 3 ~ F_{1}, 574$. (d) IL-10 secretion in supernatant of each strain of transgenic mice. Mean values $(\mathrm{pg} / \mathrm{ml})$ with medium were: DQ6, 27; DQ8, 21.4; DR3, 28; DQ8×DR3 F1, 21.79.

molecules. Those studies demonstrated that the sequence $\alpha 320-337$ was recognized by several MG patients $(31,44,45)$, and that this sequence could bind effectively to three of the four DR molecules tested (DR2, DR4, and DR7) (44). T cell lines were generated against the full-length recombinant $\mathrm{H}$-AChR $\alpha$ subunit (41); peptides $75-115$ and 138-167 were restricted by DR4, and peptide 309-344 was restricted by DR3 or DR52a (41). However, those studies did not examine the association of any particular dominant $\mathrm{H}-\mathrm{AChR} \mathrm{T}$ cell epitopes with a particular HLA-DQ molecule.

In our current study, we used HLA-DQ8 and DR3 transgenic mice to identify the dominant H-AChR- $\alpha$ subunit $\mathrm{T}$ cell epitopes recognized by $\mathrm{T}$ cells during the primary and secondary immune response to $\mathrm{H}-\mathrm{AChR}$. To reproduce as closely as possible what may occur in the pathogenesis of human MG, we immunized DQ8 and DR3 transgenic mice with intact $\mathrm{H}$-AChR. Therefore, DQ8- and DR3-expressing antigen-presenting cells processed the H-AChR and presented selected peptides to the T cells. DQ8, DR3, DQ8 $\times$ DR3 $F_{1}$, and DQ8 $\times$ DQ6 $\mathrm{F}_{1}$ mice generated anti-AChR Ab and developed clinical EAMG after multiple immunizations with $\mathrm{H}$-AChR. Thus, we have demonstrated here, for the first time to our knowledge that EAMG can be induced in HLA transgenic mice by immunizing with $\mathrm{H}-\mathrm{AChR}$. T-AChR-immune T cells of C57BL/6 (I-A ${ }^{\mathrm{b}}$ ) mice predominantly respond to epitopes within the sequence region 146-169 of the T-AChR $\alpha$ subunit (20). T cells from HLA-DQ8 and DR3 transgenic mice immunized with T-AChR recognized primarily epitopes within $141-160$ and $170-180$ of the H-AChR $\alpha$ subunit. However, H-AChR-immune T cells of DQ8 and DR3 transgenic mice responded predominantly to a dominant epitope within residues $H-\alpha 320-337$. These data clearly suggest that $\mathrm{T}$ cells of $\mathrm{DQ} 8$ mice immunized with T-AChR and $\mathrm{H}$-AChR recognize different epitopes in the $\mathrm{H}$-AChR $\alpha$ subunits. DQ8 mouse T cells responded to most of the peptides recognized by $\mathrm{T}$ cells of $\mathrm{H}$-AChR-immune DR3 mice. For H-AChR-sensitized DQ8 mice, peptide $\mathrm{H}-\alpha 320-337$ was the dominant epitope. In DR3 mice the anti-H-AChR-immune T cells responded to a number of peptide sequences of the $\mathrm{H}$-AChR $\alpha$ subunit. The DR3 allele has been associated with several autoimmune diseases. The ability of DR3 transgenic mouse $\mathrm{T}$ cells to respond to several $\mathrm{H}-\mathrm{AChR}$ peptides implies that the DR3 molecule can bind numerous epitopes and activate a variety of $T$ cells.

The sequence $\mathrm{H}-\alpha 320-337$, which is part of the cytoplasmic domain of the H-AChR, might form a promiscuous epitope (44), recognized by $T$ cells of $M G$ patients with different HLA-DQ or DR alleles, beside the DQ8 and DR3 alleles. The finding that this peptide

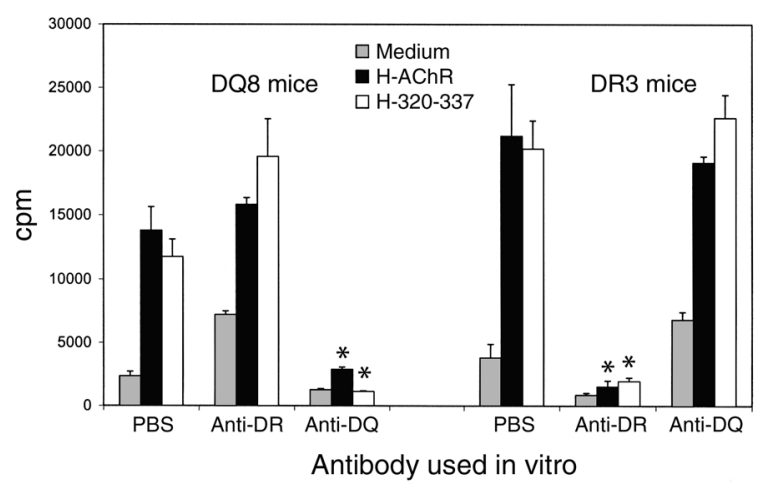

Figure 8

Effect of anti-DR or -DQ Ab on in vitro AChR- and $\alpha 320-337$ peptide-specific lymphocyte proliferation response. Pooled LNCs from four $\mathrm{H}$-AChR-immunized DQ8 mice and four $\mathrm{H}$-AChR-immunized DR3 mice were cultured in vitro with $\mathrm{H}$-AChR $(0.5 \mu \mathrm{g} / \mathrm{ml})$ or $\mathrm{H}-\alpha 320-337$ peptide $(40 \mu \mathrm{g} / \mathrm{ml})$, and anti-HLA-DQ or anti-HLA$\operatorname{DR} \mathrm{mAb}(2.5 \mu \mathrm{g} / \mathrm{ml}) .{ }^{*} P<0.05$, Student's t test. 
is frequently recognized by $\mathrm{CD} 4^{+}$cells of $\mathrm{MG}$ patients, irrespective of their class II haplotype $(30,31)$, supports this possibility. Identification of one dominant epitope H- $\alpha 320-337$ for two HLA alleles (DQ8 and DR3) closely linked to MG susceptibility goes beyond the primary mapping of $\mathrm{H}-\mathrm{AChR} \mathrm{T}$ cell epitope in MG patients. Epitopes within this sequence could sensitize $\mathrm{CD}^{+} \mathrm{T}$ cells during the initial priming with $\mathrm{H}-\mathrm{AChR}$ or with a cross-reactive antigen (i.e., microbial antigen). It is also possible that when the mouse neuromuscular junction $\mathrm{AChR}$ is destroyed by Ab binding and complementmediated lysis, AChR fragments could be processed, and dominant epitope(s) (including $\alpha 320-337$ ) could be presented to $T$ cells and maintain the autoimmune $\mathrm{T}$ cell response to the AChR.

The relative resistance to clinical EAMG of DQ6 mice after immunization with $\mathrm{H}-\mathrm{AChR}$ and the negative association of the DQ6 allele with human MG could imply that the DQ6 molecule is less efficient in binding and/or presentation of dominant pathogenic $\mathrm{T}$ cell epitopes of the H-AChR. It is also possible that individuals bearing the DQ6 allele have reduced $\mathrm{T}$ cells potentially reactive to AChR T epitopes. MHC class II molecules influence the peptide-binding characteristics during immune response. HLA-DQ8 and DR3 bind few or more autoantigenic peptides that contribute to MG development, and the DQ6 molecule either does not bind these autoantigenic peptides, or else binds them in an altered binding motif such that different residues could be presented to the $\mathrm{T}$ cell receptor.

There was no difference in the anti-AChR IgM Ab response in $\mathrm{H}-\mathrm{AChR}$-immunized DQ8, DR3, and $\mathrm{F}_{1}$ mice (all susceptible to EAMG), and the EAMG-resistant DQ6 mice. However, all the serum anti-AChR IgG isotypes we tested $\left(\operatorname{IgG}_{1}, \operatorname{IgG}_{2 \mathrm{~b}}\right.$, and $\left.\operatorname{IgG}_{2 \mathrm{c}}\right)$ were lower in DQ6 mice than in DQ8, DR3, and $\mathrm{F}_{1}$ mice. This suggests that the $\mathrm{B}$ cells of DQ6 mice have antigen receptors specific for mouse AChR in normal numbers, but less capable of mounting a secondary $\mathrm{Ab}$ response to the mouse AChR. The overall $\mathrm{T}$ cell response to the $\mathrm{H}-\mathrm{AChR} \alpha$ subunit epitopes leads to a strong production of cytokines (i.e., IL-2 and IFN- $\gamma$ ), which may activate $\mathrm{H}-\mathrm{AChR}$-specific B cells in DQ8 and DR3 mice. The defect in switching from antiAChR IgM to IgG could be due to the reduced T cell responses, and the reduced IFN- $\gamma$ and IL- 2 production that we observed in DQ6 mice after immunization with H-AChR. Also, the resistance of HLA-DQ6 mice to EAMG induced by immunization with T-AChR was associated with a reduced AChR-specific production of IFN- $\gamma$, IL-2, and IL-10 (46).

It is of interest that $\mathrm{H}$-AChR-immune $\mathrm{T}$ cells of both DQ8 and DR3 mice, which are susceptible to EAMG, responded dominantly to the $\mathrm{H}-\alpha 320-337$ peptide. Also, the $\mathrm{H}-\alpha 320-337$ peptide response was dominant in DQ8 $\times$ DQ6 $\mathrm{F}_{1}$ mice. The I- $\mathrm{A}^{\mathrm{b}}$ gene was codominant for clinical EAMG susceptibility when mice were immunized with T-AChR (47). Thus, one MG-suscep- tible HLA-DQ allele in a heterozygote could be sufficient for full expression of MG.

We report several new findings in this paper: (a) H-AChR derived from TE671 muscle-like cell line has been purified by neurotoxin affinity chromatography. (b) EAMG was successfully induced in HLA class II transgenic mice by immunizing with H-AChR. (c) The DQ8 gene conferred susceptibility to clinical EAMG and $\mathrm{T}$ cell responsiveness to the dominant peptides H- $\alpha 320-337$, according to a pattern of dominant inheritance. (d) The resistance to EAMG of DQ6 mice was associated with a reduced secondary anti-AChR IgG response, but not with the anti-AChR IgM response. (e) The EAMG resistance of DQ6 mice was associated with a reduced H-AChR-specific production of IFN- $\gamma$ and IL-2. (f) We have characterized the dominant human class II-restricted H-AChR $\alpha$ subunit $\mathrm{T}$ cell epitope H- $\alpha 320-337$ for DQ8 and DR3 transgenic mice.

EAMG can be prevented or suppressed in T-AChRprimed I- $\mathrm{A}^{\mathrm{b}}$ mice by injection of high doses of T- $\alpha 146-162$ peptide in incomplete Freund's adjuvant or by nasal or subcutaneous treatment with solutions of the peptide T- $\alpha 150-169$ (20-23). The H-AChR peptide $\alpha 320-337$, identified here as immunodominant in DR3 and DQ8 transgenic mice, might be used for similar therapeutic tolerance approaches in MG patients.

\section{Acknowledgments}

This study was supported by the Muscular Dystrophy Association (P. Christadoss) and the NIH (National Institute of Neurological Disease and Stroke NS23919; B. Conti-Fine). H. Yang was a Myasthenia Gravis Foundation Osserman/Sosin/McClure postdoctoral fellow and is now an MDA Neuromuscular Disease Research Career Award recipient. M.A. Poussin was a recipient of consecutive postdoctoral fellowship awards from the Association Francaise contre les Myopathies, the Myasthenia Gravis Foundation (Osserman/Sosin/McClure), and the McLaughlin Foundation and is now an MDA Neuromuscular Disease Research Career Award recipient.

1. Drachman, D.B. 1994. Myasthenia gravis. N. Engl. J. Med. 330:1797-1810. 2. Engel, A.G., Lambert, E.H., and Howard, F.M. 1977. Immune complexes (IgG and C3) at the motor end plate in myasthenia gravis: ultra structural and light microscopic localization and electrophysiologic correlations. Mayo Clin. Proc. 52:267-280.

3. Conti-Fine, B.M., Bellone, M., Howard, J.F., Jr., and Protti, M.P. 1997. Myasthenia gravis: the immunobiology of an autoimmune disease. R.G. Landes, editor. Chapman \& Hall, Springer. Austin, Texas, USA. 230 pp.

4. Christadoss, P., Poussin, M., and Deng, C. 2000. Animal models of myasthenia gravis. Clin. Immunol. 94:75-87.

5. Christadoss, P., Lindstrom, J., Munro, S., and Talal, N. 1985. Muscle acetylcholine receptor loss in murine experimental autoimmune myasthenia gravis: correlated with cellular, humoral and clinical responses. J. Neuroimmunol. 8:29-41.

6. Christadoss, P. 1988. C5 gene influences the development of murine myasthenia gravis. J. Immunol. 140:2589-2592.

7. Christadoss, P., Lennon, V.A., Krco, C.J., and David, C.S. 1982. Genetic control of experimental autoimmune myasthenia gravis in mice. III. Ia molecules mediate cellular immune responsiveness to acetylcholine receptors. J. Immunol. 128:1141-1144.

8. Kaul, R., Shenoy, M., Goluszko, E., and Christadoss, P. 1994. Major histocompatibility complex class II gene disruption prevents experimental autoimmune myasthenia gravis. J. Immunol. 152:3152-3157.

9. Christadoss, P., Lindstrom, J.M., Melvold, R.W., and Talal, N. 1985. 
Mutation at I-A beta chain prevents experimental autoimmune myasthenia gravis. Immunogenetics. 21:33-38.

10. Christadoss, P., and Dauphinee, M.J. 1986. Immunotherapy for myasthenia gravis: a murine model. J. Immunol. 136:2437-2440.

11. Bell, J., et al. 1986. HLA-DQ beta-chain polymorphism linked to myasthenia gravis. Lancet. 1:1058-1060.

12. Naeim, F., et al. 1978. Association of HLA-B8, DRw3, and anti-acetylcholine receptor antibodies in myasthenia gravis. Tissue Antigens. 12:381-386.

13. Hjelmstrom, P., et al. 1996. Polymorphic amino acid domains of the HLA-DQ molecule are associated with disease heterogeneity in myasthenia gravis. J. Neuroimmunol. 65:125-131.

14. Raju, R., et al. 1998. Polymorphism at the HLA-DQ locus determines susceptibility to experimental autoimmune myasthenia gravis. J. Immunol. 160:4169-4174.

15. Raju, R., Spack, E.G., and David, C.S. 2001. Acetylcholine receptor peptide recognition in HLA DR3-transgenic mice: in vivo responses correlate with MHC-peptide binding. J. Immunol. 167:1118-1124.

16. Bellone, M., Ostlie, N., Lei, S., and Conti-Tronconi, B. 1991. Experimental myasthenia gravis in congenic mice. Sequence mapping and $\mathrm{H}-2$ restriction of Thelper epitopes on the subunits of Torpedo californica and murine acetylcholine receptors. Eur. J. Immunol. 21:2303-2310.

17. Bellone, M., Ostlie, N., Lei, S., Wu, X.-D., and Conti-Tronconi, B. 1991. The I- $\mathrm{A}^{\mathrm{bm} 12}$ mutation, which confers resistance to experimental myasthenia gravis, drastically affects the epitope repertoire of murine CD4 cells sensitized to nicotinic acetylcholine receptor. J. Immunol. 147:1484-1491.

18. Infante, A., Thompson, P., Krolik, K., and Wall, K. 1991. Determinant selection in murine experimental autoimmune myasthenia gravis: effect of the bm12 mutation on T-cell recognition of acetylcholine receptor epitopes. J. Immunol. 146:2977-2982.

19. Shenoy, M., Oshima, M., Atassi, M.Z., and Christadoss, P. 1993. Suppression of experimental autoimmune myasthenia gravis by epitope-specific neonatal tolerance to synthetic region alpha 146-162 of acetylcholine receptor. Clin. Immunol. Immunopathol. 66:230-238.

20. Wu, B., Deng, C., Goluszko, E., and Christadoss, P. 1997. Tolerance to a dominant $\mathrm{T}$ cell epitope in the acetylcholine receptor molecule induces epitope spread and suppresses murine myasthenia gravis. J. Immunol. 159:3016-3023.

21. Karachunski, P., Ostlie, N., Okita, D., and Conti-Fine, B.M. 1997. Prevention of experimental myasthenia gravis by nasal administration of synthetic acetylcholine receptor $\mathrm{T}$ epitope sequences. J. Clin. Invest. 100:3027-3035.

22. Karachunski, P.I., Ostlie, N.S., Okita, D.K., Garman, R., and Conti-Fine, B.M. 1999. Subcutaneous administration of T epitope sequences of the acetylcholine receptor prevents experimental myasthenia gravis. J. Neuroimmunol. 93:108-121.

23. Deng, C., Goluszko, E., and Christadoss, P. 2001. Fas/Fas ligand pathway, apoptosis, and clonal anergy involved in systemic acetylcholine receptor T cell epitope tolerance. J. Immunol. 166:3458-3467.

24. Abraham, R.S., et al. 1999. NOD background genes influence T cell responses to GAD 65 in HLA DQ8 transgenic mice. Hum. Immunol. 60:583-590

25. Abraham, R.S., Kudva, Y.C., Wilson, S.B., Strominger, J.L., and David, C.S. 2000. Co-expression of HLA DR3 and DQ8 results in the development of spontaneous insulitis and loss of tolerance to GAD65 in transgenic mice. Diabetes. 49:548-554.

26. Wu, B., Goluszko, E., and Christadoss, P. 1997. Experimental autoimmune myasthenia gravis in the mouse. In Current protocols of immunology. Volume 3:15. M. J.E. Coligan, A.M. Kruisheek, D.H. Margulies, E.M. Shevach, and W. Strober, editors. John Wiley \& Sons. New York, New York, USA. 8.1-8.16.

27. Lindstrom, J., Merlie, J., and Yogeeswaran, G. 1979. Biochemical properties of acetylcholine receptor subunits from Torpedo californica. Biochemistry. 18:4465-4470.

28. Houghten, R.A. 1985. General method for the rapid solid phase synthesis of large numbers of peptides: specificity of antigen-antibody interac- tion at the level of individual amino acids. Proc. Natl. Acad. Sci. USA 82:7042-7052.

29. Protti, M.P., Manfredi, A.A., Straub, C., Howard, J., and Conti-Tronconi, B.M. 1990. CD4 ${ }^{+}$T cell response to human acetylcholine receptor $\alpha$ subunit in myasthenia gravis. A study with synthetic peptides. J. Immunol. 144:1276-1281.

30. Protti, M.P., Manfredi, A.A., Straub, C., Howard, J.F., and Conti-Tronconi, B.M. 1990. Immunodominant regions for T-helper sensitization on the human nicotinic receptor $\alpha$ subunit in myasthenia gravis. Proc. Natl. Acad. Sci. USA. 87:7792-7796.

31. Manfredi, A.A., Protti, M.P., Wu, X.D., Howard, J.F., Jr., and Conti-Tronconi, B.M. 1992. CD4 ${ }^{+}$T-epitope repertoire on the human acetylcholine receptor $\alpha$ subunit in severe myasthenia gravis. A study with synthetic peptides. Neurology. 42:1092-1100.

32. Protti, M.P., et al. 1991. Myasthenia gravis. T-epitopes on the $\delta$ subunit of human muscle acetylcholine receptor. J. Immunol. 146:2253-2261.

33. Wang, Z.Y., Okita, D.K., Howard, J., Jr., and Conti-Fine, B.M. 1997. Th1 epitope repertoire on the alpha subunit of human muscle acetylcholine receptor in myasthenia gravis. Neurology. 48:1643-1653.

34. Christadoss, P., David, C.S., Shenoy, M., and Keve, S. 1990. E $\alpha^{\mathrm{K}}$ transgene in B10 mice suppresses the development of myasthenia gravis. Immunogenetics. 31:241-244.

35. Moiola, L., Karachunski, P., Protti, M.P., Howard, J.F., Jr., and ContiTronconi, B.M. 1994. Epitopes on the beta subunit of human muscle acetylcholine receptor recognized by CD4+ cells of myasthenia gravis patients and healthy subjects. J. Clin. Invest. 93:1020-1028.

36. Protti, M.P., et al. 1992. Myasthenia gravis: CD4 ${ }^{+} \mathrm{T}$ epitopes on the embryonic $\gamma$ subunit of human muscle acetylcholine receptor. J. Clin. Invest. 90:1558-1567.

37. Manfredi, A.A., Protti, M.P., Dalton, M.W.M., Howard, J.F., Jr., and ContiTronconi, B.M. 1993. T helper cell recognition of muscle acetylcholine receptor in myasthenia gravis: epitopes on the $\gamma$ and $\delta$ subunits. J. Clin. Invest. 92:1055-1067.

38. Miola, L., Protti, M.P., Howard, J.F., Howard, J.F., and Conti-Tronconi, B.M. 1994. Myasthenia gravis: residues of the $\alpha$ and $\gamma$ subunits of muscle acetylcholine receptor involved in formation of immunodominant CD4+ epitopes. J. Immunol. 152:4686-4698.

39. Wang, Z.Y., Okita, D.K., Howard, J.F., Jr., and Conti-Fine, B.M. 1997. Th1 epitope repertoire on the $\alpha$ subunit of human muscle acetylcholine receptor in myasthenia gravis. Neurology. 48:1643-1653.

40. Wang, Z.Y., Okita, D., Howard, J.F., Jr., and Conti-Fine, B.M. 1998. CD4 $\mathrm{T}$ cell recognition of the $\varepsilon$ subunit of human muscle acetylcholine receptor in myasthenia gravis. J. Neuroimmunol. 91:33-42.

41. Matsuo, H., et al. 1995. Peptide-selected T cell lines from myasthenia gravis patients and controls recognize epitopes that are not processed from whole acetylcholine receptor. J. Immunol. 155:3683-3692.

42. Harcourt, G.C., Sommer, N., Rothbard, J., Willcox, H.N.A., and NewsomDavis, J. 1988. A juxta-membrane epitope on the human acetycholine receptor recognized by $\mathrm{T}$ cells in myasthenia gravis. J. Clin. Immunol. 82:1295-1300.

43. Hill, M., et al. 1999. Early-onset myasthenia gravis: a recurring T-cell epitope in the adult-specific acetylcholine receptor subunit presented by the susceptibility allele HLA-DR52a. Ann. Neurol. 45:224-231.

44. Manfredi, A., Yuen, M.H., Moiola, L., Protti, M.P., and Conti-Tronconi, B.M. 1994. Human acetylcholine receptor presentation in myasthenia gravis: DR restriction of autoimmune $T$ epitopes and binding of synthetic receptor sequences to DR molecules. J. Immunol. 152:4165-4174.

45. Yuen, M.H., Macklin, K., and Conti-Fine, B.M. 1996. MHC class II presentation of human acetylcholine receptor in myasthenia gravis. Binding of synthetic gamma subunit sequences to purified DR molecules. J. Autoimmun. 9:67-77.

46. Poussin, M.A., Goluszko, E., David, C.S., Franco, J.U., and Christadoss, P. 2001. HLA-DQ6 transgenic mice resistance to experimental autoimmune myasthenia gravis is linked to reduced AChR-specific IFN- $\gamma$, IL-2, and IL-10 production. J. Autoimmun. 17:175-180.

47. Christadoss, P. 1989. Immunogenetics of experimental autoimmune myasthenia gravis. Crit. Rev. Immunol. 9:247-278. 